Giuseppe Fabrini

\title{
Seed germination data of Sporobolus aculeatus (Poaceae) and Juncus subulatus (Juncaceae)
}

\begin{abstract}
Fabrini, G.: Seed germination data of Sporobolus aculeatus (Poaceae) and Juncus subulatus (Juncaceae) [In Magrini, S. \& Salmeri, C. (eds), Mediterranean plant germination reports - 1]. Fl. Medit. 29: 303-306. 2019. https://doi.org/10.7320/FlMedit29.303

The most significant results of seed germination of Sporobolus aculeatus (L.) P.M.Peterson and Juncus subulatus Forssk. are reported. The seeds were collected from the Natural Monument "Palude di Torre Flavia" in Latium. The highest germination value $(92.0 \%)$ for S. aculeatus seeds were obtained after 2 months of cold stratification and then incubation at an alternating temperature of $20 / 10^{\circ} \mathrm{C}$ in continuous darkness. For $J$. subulatus, the best germination value $(95.0 \%)$ were obtained with alternating temperatures, $20 / 10^{\circ} \mathrm{C}$ and $15 / 6^{\circ} \mathrm{C}$, under a $12 / 12 \mathrm{~h}$ (light/dark) photoperiod.
\end{abstract}

Key words: cold stratification, degradation of wetland habitats, Latium, retrodunal humid depressions.

21. Sporobolus aculeatus (L.) P.M.Peterson (Poaceae) (Fig. 1)

\section{Accession data}

It: Latium. Ladispoli, Cerveteri (Roma), loc. Monumento Naturale "Palude di Torre Flavia" (WGS84: 41.963194 $\mathrm{N}, 12.044944^{\circ} \mathrm{E}$ ), area umida, $0 \mathrm{~m}$ a.s.1., 7 Oct 2008, M. Giovannetti \& G. Fabrini (BGR-1431028S07101014A2 12, Rome Germplasm Bank).

\section{Germination data}

Pre-treatments: cold stratification in moistened sand $\left(0,1,2\right.$ months at $\left.5^{\circ} \mathrm{C}\right)(\mathrm{Côme} \mathrm{1970).}$

Germination medium: Petri dishes with Whatman Filter Papers N.2 soaked in distilled water.

Sample size: 120 seeds for each test $(30 \times 4$ replicates $)$. 


\begin{tabular}{|c|c|c|c|c|c|c|c|}
\hline Germination & $\begin{array}{c}\text { Stratification } \\
{[\text { months] }}\end{array}$ & Thermoperiod & $\begin{array}{c}\text { Photoperiod } \\
{[\text { light/dark] }}\end{array}$ & $\mathbf{T}_{\mathbf{1}}[\mathbf{d}]$ & $\mathbf{T}_{\mathbf{5 0}}[\mathbf{d}]$ & $\mathbf{T}_{\max }[\mathbf{d}]$ & $\mathbf{M T G}[\mathbf{d}]$ \\
\hline $\mathbf{9 2 . 0} \%$ & 2 & $20 / 10^{\circ} \mathrm{C}$ & $0 / 24 \mathrm{~h}$ & 3.0 & 9.0 & 9.0 & 8.5 \\
\hline $\mathbf{8 6 . 0} \%$ & 1 & $20 / 10^{\circ} \mathrm{C}$ & $12 / 12 \mathrm{~h}$ & 3.0 & 15.0 & 27.0 & 14.2 \\
\hline $\mathbf{8 5 . 0} \%$ & 2 & $20 / 10^{\circ} \mathrm{C}$ & $12 / 12 \mathrm{~h}$ & 3.0 & 12.0 & 24.0 & 11.6 \\
\hline
\end{tabular}

\section{Observations}

The degradation of wetland habitats is becoming more and more sensitive worldwide. This degradation also affects the territory included in the municipalities of Ladispoli and Cerveteri, which houses the Natural Monument "Palude di Torre Flavia" and the studied species. The progressive reclamation, urbanization and the continuous withdrawal of groundwater have created an alteration of the hydrological regime, with serious consequences for habitats and ecosystems (Battisti 2006).

The seeds of $S$. aculeatus are of the orthodox type, with a moisture content of ca. $8.4 \%$. They are subject to a physiological dormancy (Baskin \& Baskin 1998). In the studied area, the species completes the entire biological cycle between March and September. S. aculeatus colonizes retrodunal humid depressions areas and lives in association with many species typical of fresh and brackish water environments, in particular Bolboschoenus maritimus (L.) Palla.

Seed germination tests were conducted at $5^{\circ} \mathrm{C}, 20 / 10^{\circ} \mathrm{C}, 15 / 6^{\circ} \mathrm{C}, 25 / 15^{\circ} \mathrm{C}(12 \mathrm{~h}$ light $/ 12$ dark and continuous dark) (Bacchetta $\&$ al. 2006). The results obtained from this study contribute to a better knowledge of seed germination ecology of this annual species, Critically Endangered in Latium (Conti \& al. 1997), as no data on its germination were found in the literature.

\section{Juncus subulatus Forssk. (Juncaceae) (Fig. 2)}

\section{Accession data}

It: Latium. Ladispoli, Cerveteri (Roma), loc. Monumento Naturale "Palude di Torre Flavia" (WGS84: $\left.41.963194^{\circ} \mathrm{N}, 12.044944^{\circ} \mathrm{E}\right)$, area umida, 0 m a.s.1., 10 Oct 2010, M. Giovannetti \& G. Fabrini (BGR-1338028S10100911 A4, Rome Germplasm Bank).

\section{Germination data}

Pre-treatments: cold stratification in moistened sand (0, 1, 2, 3 months at $\left.5^{\circ} \mathrm{C}\right)$ (Côme 1970).

Germination medium: Petri dishes with Whatman Filter Papers N.2 soaked in distilled water.

Sample size: 100 seeds $(25 \times 4$ replicates for each test $)$. 


\begin{tabular}{|c|c|c|c|c|c|c|c|}
\hline Germination & $\begin{array}{c}\text { Stratification } \\
{[\text { months] }}\end{array}$ & Thermoperiod & $\begin{array}{c}\text { Photoperiod } \\
{[\text { light/dark] }}\end{array}$ & $\mathbf{T}_{\mathbf{1}}[\mathbf{d}]$ & $\mathbf{T}_{\mathbf{5 0}}[\mathbf{d}]$ & $\mathbf{T}_{\text {max }}[\mathbf{d}]$ & $\mathbf{M T G}[\mathbf{d}]$ \\
\hline $\mathbf{9 5 . 0} \%$ & 0 & $15 / 6^{\circ} \mathrm{C}$ & $12 / 12 \mathrm{~h}$ & 12.0 & 12.0 & 24.0 & 13.0 \\
\hline $\mathbf{9 5 . 0} \%$ & 0 & $20 / 10^{\circ} \mathrm{C}$ & $12 / 12 \mathrm{~h}$ & 6.0 & 9.0 & 24.0 & 9.4 \\
\hline $\mathbf{8 6 . 0} \%$ & 0 & $25 / 15^{\circ} \mathrm{C}$ & $12 / 12 \mathrm{~h}$ & 6.0 & 6.0 & 12.0 & 8.4 \\
\hline $\mathbf{8 5 . 0} \%$ & 3 & $15 / 6^{\circ} \mathrm{C}$ & $12 / 12 \mathrm{~h}$ & 12.0 & 12.0 & 24.0 & 13.9 \\
\hline
\end{tabular}

\section{Observations}

Juncus subulatus is a perennial rhizomatous geophyte. It is found in marshes, wet sands and moist grounds in salt and freshwater. It is native to the Mediterranean and IranoTuranian Regions and occurs in central and south Italy (Bartolucci \& al. 2018). In the IUCN Red List of Threatened Species, it is listed as Least Concern (LC) at the global and Mediterranean level as it is widespread with stable populations and does not face any major threats (de Belair \& Lansdown 2014).

Seed germination tests were conducted at $5^{\circ} \mathrm{C}, 20 / 10^{\circ} \mathrm{C}, 15 / 6^{\circ} \mathrm{C}$ and $25 / 15^{\circ} \mathrm{C}(12 \mathrm{~h}$ light/12 h dark and continuous dark) (Bacchetta $\&$ al. 2006). The obtained results showed that $J$. subulatus produces non-dormant seeds, which are also markedly affected by photoinhibition, as highlighted by the almost total absence of germination in dark conditions at all tested thermoperiods.

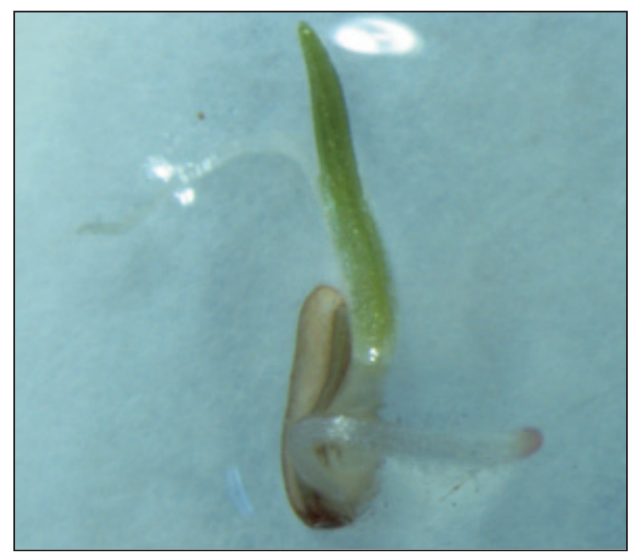

Fig. 1. Germinated seeds of Sporobolus aculeatus.

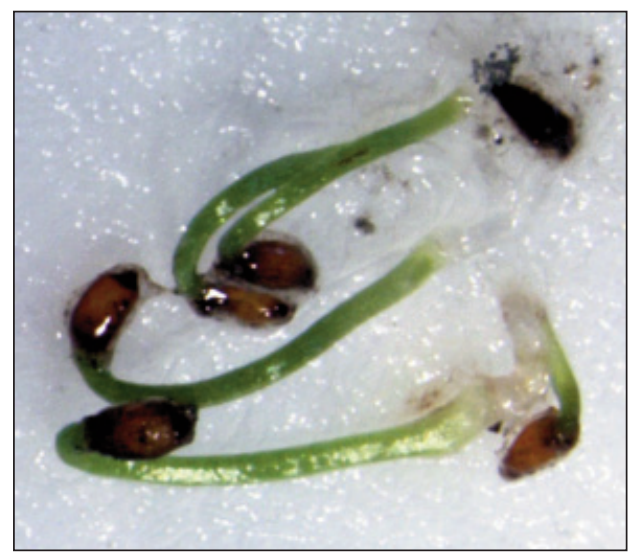

Fig. 2. Germinated seed of Juncus subulatus. 


\section{References}

Bacchetta, G., Fenu, G., Mattana, E., Piotto, B. \& Virevaire, M. 2006: Manuale per la raccolta, studio, conservazione e gestione ex situ del germoplasma. Manuali e linee guida APAT 37/2006. - Roma.

Bartolucci, F., Peruzzi, L., Galasso, G., Albano, A., Alessandrini, A., Ardenghi, N. M. G., Astuti, G., Bacchetta, G., Ballelli, S., Banfi, E., Barberis, G., Bernardo, L., Bouvet, D., Bovio, M., Cecchi, L., Di Pietro, R., Domina, G., Fascetti, S., Fenu, G., Festi, F., Foggi, B., Gallo, L., Gubellini, L., Gottschlich, G., Iamonico, D., Iberite, M., Jiménez-Mejías, P., Lattanzi, E., Martinetto, E., Masin, R. R., Medagli, P., Passalacqua, N. G., Peccenini, S., Pennesi, R., Pierini, B., Poldini, L., Prosser, F., Raimondo, F. M., Marchetti, D., Roma-Marzio, F., Rosati, L., Santangelo, A., Scoppola, A., Scortegagna, S., Selvaggi, A., Selvi, F., Soldano, A., Stinca, A., Wagensommer, R. P., Wilhalm, T. \& Conti, F. 2018: An updated checklist of the vascular flora native to Italy. - Pl. Biosyst. 152: 179-303. https://doi.org/10.1080/ 11263504.2017 .1419996

Baskin, C. C. \& Baskin, J. M. 1998: Seeds: Ecology, Biogeography and evolution of dormancy and germination. - New York.

Battisti, C. 2006: Biodiversità, gestione, conservazione di un'area umida del litorale tirrenico. La Palude di Torre Flavia. - Roma.

Belair de, G. \& Lansdown, R. V. 2014: Juncus subulatus. The IUCN Red List of Threatened Species 2014: e.T164124A13559608. http://dx.doi.org/10.2305/IUCN.UK.2014-1.RLTS.T16412 4A13559608.en

Côme, D. 1970: Les obstacles à la germination. - Paris.

Conti, F., Manzi, A. \& Pedrotti, F. 1997: Liste rosse Regionali delle Piante d'Italia. - Camerino.

Address of the author:

Giuseppe Fabrini,

Department of Environmental Biology, Sapienza University of Rome, P.le A. Moro

5, I-00185 Rome, Italy. E-mail: giuseppe.fabrini@uniroma1.it 